\title{
A Comparative Study on Impact of Venture Capital Financing on Startups in India
}

\author{
Kishan Kumar Shetty
}

\begin{abstract}
Startups have played a strategic role in stimulating economic development and industrialization in the country .With a significant demand in entrepreneurship in India, we see a proliferating growth in the number of startups over the past few years. On the basis of the Economic Survey 2015-2016 released by the government, the Indian start up ecosystem has shown a tremendous growth having more than 19,000 technology-enabled startups, mainly dominated by consumer technology sector and financial services startups.

With this kind of considerable increase in the number of startups in the country, it is essential to find out how they finance in such an immensely challenging environment to achieve high prospects of growth and survival. This paper focuses on venture capital with the concept of 'your idea and our money' as source of finance for the business start-ups characterized by high risk and long term growth perspective to turn into a sound, well-developed business model and how the venture capital industry has grown in various sectors by having a comparative analy sis of venture capital financing.
\end{abstract}

Keywords - Venture, Financing.

\section{INTRODUCTION}

Venture capital in India was eminent since the nineties and have successfully aided young hi-tech business with risky projects and high growth prospects by providing financial support in the form of seed capital, shares and other means. In 1988, ICICI with Unit Trust of India came up as a venture capital provider in India and played a prominent role in actively encouraging venture capital financing. Presently there are large number of venture capitalist and Angel investors and have helped the startup ecosystem prosper till date in India. As there is lot of fluctuations in rapidly developing economies, the venture capital has also experienced to have its own paradigm shifts with its existence seen globally and has taken different forms varying from raising funds globally and cross border investment to foreign acquisition and helping overseas companies to access the market in different regions.

With 10,000 and more startups along with the quantum of investments made, India is considered to be the third largest country to have fastest growing and largest start up community making India one of the leading destinations of venture capital and private equity financing and has shown a significant contribution in boosting the economic growth of the country. Startups are subjected to high amount of risk and their financing plays a paramount role since they help startups at early stages to reach the level of profitability and sustainable growth in the market. There are various sources of equity financing for young entrepreneurs and startups which includes Angel Investors, Venture capital financing, Corporate venture capital and private equity .This paper focuses on venture capital as a source of finance- their investment trends and activities on three transactional economies namely USA, China and India and tries to provide an insight by comparing Indian venture capital sector with China and USA. It has also focused on venture capital financing sector specifically in the Indian Economy in the year 2014 and 2015

\section{CONCEPT OF VENTURE CAPIT AL FINANCING}

A young hi-tech enterprise that is subjected to high risk in its early stage will not be able to make public issue or have access to capital markets and hence depend on venture capital financing. Venture capital is a long term, secured and stable capital provided in the form of equity finance to startups with high risk in their early stage. Venture capitalist generally invest in hi-tech industries such as Software Company, biotechnology, consumer internet and other industries with high risk and exceptional growth potentials with an aim to earn high rate of return on their investments. Apart from providing funding for the enterprise, they also provide domain knowledge and expertise to help the company to attain full potentials. When the business is able to earn substantial profits and considerable growth in market share, venture capitalists sell off their equity holdings of the enterprise at a high value and hence make capital gains.

The investment process of venture capital starts with identification of a feasible investment opportunity which involves sourcing of deals followed by the screening process where analysis and detailed background of the business plan is checked. Once the deals is considered to be worthy, the opportunity is furnished to the internal investment committee for approval followed by signing the investment documents. During the holding period, the investment is monitored by a fund manager along with a domain expert to add value to the company. They usually require a seat in the Board of the company they invest in and has a continuous involvement in the company after making their investment. Ultimately, once the company reaches its full potentials, venture capitalists exits the investment by selling their holdings though an IPO, sale to other financial intermediaries or promoters buyback 


\section{OBJECTIVE OF THE STUDY}

To understand the venture capital financing activities in India in 2014 and 2015 and have a comparative analysis of venture capital financing of India with China and USA.

\section{METHOdOLOGY OF THE ST UDY}

Secondary data such as journals and authentic reports are used to for the purpose of doing this study.

\section{Comparative analysis on venture capital financing activities in USA, China and India}

2014 witnessed a high level of venture capital financing in USA and China compared to the level seen in 2008 since there was improving economic conditions that supported the fundraising environment globally. In US the investment done by venture capitalist increased by $47 \%$ and tripled for China in contrast to 2013. The Chinese economy had seen a robust activity in information technology and consumer services sector resulting in rapid increase in Venture Capital funding. When compared to the smaller markets, India was an exception. There was continuous upward trend in venture capital investment in the fourth quarter due to consumer services sector based companies -flipkart.com and snapdeal.com that increased the investment to $35 \%$ compared to the third quarter of 2014. It was seen that venture capital deals were more dominant in information technology, consumer service sector and mobile-based platform company like Uber technologies, snapchat, flipkart.com etc. Investors were interested in two emerging markets-India and China and there was threefold increase in funding level in the last quarter of 2014.

In 2015, with more than 3,916 deals, the US economy continued to dominate the Venture capital landscape even after having a strong dollar and hike in Federal Reserve rate. It was observed there was a growing significance of venture capital activities in china. For the first time, among the top five venture capital deals, the top three deals were done outside the US and all were done in china. Over the past five years VC funding in china has recorded a seven-fold increase and were able to make 1635 deals in 2015. However, US remained as the top investors in 2015 even though china dominated in terms of investees. When compared to China and US, India's venture capital financing is comparatively less. India was able to raise 519 deals in 2015. One of the barrier faced by the Indian economy by taking Chinese economy into comparison is the structural disadvantage where it is unable to combine its highly trained computer scientists within a more stable economy and emerging middle class hence making the markets more challenging to various investors and entrepreneurs.

An insight on venture capital activity in the Indian economy in 2014 and 2015.

Over the past decade with improving economic conditions, Indian market has matured making it as one of the most credible and reliable investment markets. Taking Indian market into account, 2014 has been a good year for consumer technology and e-commerce sector. It was seen that the top 3 deals in 2014 were majorly done in Flipkart and Snapdeal where the valuation grew more than fivefold from approximately $\$ 2$ billion to $\$ 11$ billion for Flipkart, while there was a threefold valuation for Snapdeal rising from $\$ 700$ million to $\$ 2$ billion. A significant chuck of investment was also seen in online travel companies, healthcare industry, real estate and infrastructure, banking and financial sectors along with others who provide services via internet and mobile phones. Continuous growth and usage of internet was a key factor that enabled tremendous growth in this sector. Indian venture capital deal value across various sectors and sizes grew by $28 \%$ in 2014. Other top deals were invested in following companies-Unitech corporate parks, Kotak Mahindra Bank, Shriram Capital. Some of the top Venture Capital funds were provided by, Accel Partners, Morgan Stanley Investment Mgmt, DST Advisors, GIC, Tiger Global, , Baillie Gifford \& Co. BlackRock, Tybourne Capital Mgmt. It was anticipated that mismatch in valuations expectations and rising competition are the main challenges to be faced by the venture capital space. In 2014, there was $14 \%$ increase in the number of exits and some of the factors that influenced the exit rates are macroeconomic environment (inflation), change in valuations, change in capital market and the pressure to exit and return invested capital. With the recent government reforms in various sectors like infrastructure and banking, a positive impact is seen on the business segment since there is more inflow hence resulting in more Venture Capital financing activities.

With rapid investment momentum, 2015 witnessed the emergence and evolution of startups such as Flipkart, Snapdeal, Olacabs and Paytm along with substantial increase in venture capital activity. Consumer technology remained to be the most invested sector for venture capital financing. This year also saw a decrease in inflation pressure due to fall in crude oil and other commodities resulting in fall in interest rates hence strengthening the business environment. When compared to 2014, the total venture capital deal in India increased by $51 \%$ attributing in better macroeconomic conditions and valuation expectations. Government also played an indispensable role in encouraging investments in various sectors by introducing several initiatives such as Startup India program, tax regime rationalization and Make in India, introduction of fast-track approval in industry and infrastructure projects resulting in more fund contribution and transactions in the Indian markets. The top deals in 2015 was done in the following companies -Flipkart which was funded by Tiger Global Management and Steadview Capital, One97 Communication/PayTM funded by Alibaba Group holdings and SAIF partners, Olcabs by Falcon Edge Capital, Baillie Gifford, Tiger Global Management, ACT television by TA Associate Advisory, India Value fund Advisors and many more. Another trend that was seen was active participation from corporates and multinational companies to invest in smaller companies. Considering the investment pattern in last three years, investment in core sectors like real estate, energy manufacture etc. have reduced since e-commerce companies have attracted investment .The biggest challenge to the $\mathrm{VC}$ industry in 2015 were dynamic macroeconomic factors, difficulty in raising funds and lack of ability to exit continue. 


\title{
SWOC (Strengths, Weakness, Opportunities, Challenges) Analysis of Venture Capital Financing in India
}

\author{
Strengths: \\ $\checkmark$ Profitable business with positive cash flow \\ $\checkmark$ Better and large network \\ $\checkmark$ Improving innovation \\ $\checkmark$ Quality in products
}

\section{Weakness}

$\checkmark$ Better liquidity at lower interest rates

$\checkmark$ Increase in barriers to new entrants

$\checkmark$ Favorable government policies

\section{Opportunity}

$\checkmark$ Changes in technology

$\checkmark$ Obsolescence in technology

$\checkmark$ Lack of planning and decision making

$\checkmark$ Absence of good inventory control

$\checkmark$ High cost due to inefficiency in processes

\section{Challenges}

$\checkmark$ Competition

$\checkmark$ Variations in valuation

$\checkmark$ Macroeconomic uncertainties

$\checkmark$ Difficulty in fund raising

\section{CONCLUSION}

Over the past few years the venture capital financing has shown a proliferating growth and has successfully helped young business with high risk and growth potential with financial stability. It has helped to bridge the gap where other sources of funds are not capable of funding ventures with high risk. When compared to venture financing in USA and China, Indian venture capital sector performance is relatively less but taking the Indian economy as whole there is substantial growth and rapid investment momentum mainly in the consumer technology sector making it one of the most attractive markets for venture capital investments. Effective research and development, better fiscal initiatives, adequate training and motivation are some major elements that will help venture capital industry become more successful and flourish in India. Government's initiative on improving the business environment also shows that there is a strong positive outlook for venture capital financing in India, ultimately improving the overall GDP of the country.

\section{REFERENCES}

[1] E\&Y venture capital insights 2014 and 2015

[2] Ivca.in: IVCA (Indian Private Equity \& Venture Capital Association)-Grant Thornton and Bain \& Co report 2015 \& 2016 